\title{
FSA Contribution 22: Asteraceae: Calenduleae: Garuleum
}

\author{
N. SWELANKOMO*
}

\section{INTRODUCTION}

The genus Garuleum Cass. is a member of the tribe Calenduleae in the subfamily Asteroideae of the family Asteraceae (Bremer 1994). Calenduleae comprises 12 genera, of which 11 occur naturally in southern Africa (Nordenstam 2007). Only one genus, Calendula L., is confined to the northern hemisphere, but some of its species are cultivated or occur as weeds in southern Africa. The tribe is economically important as some species are highly palatable to livestock and game, e.g. Chrysanthemoides incana (Burm.f.) Norl. (Van Breda \& Barnard 1987), while others, e.g. Dimorphotheca cuneata DC., are poisonous to stock (Watt \& Breyer-Brandwijk 1962).

Garuleum can be distinguished from other genera in the tribe by its unique style. The style of the disc florets is deeply bifurcate, with linear lobes covered with papillae to well below point of bifurcation; whereas in other genera the style of disc florets is shallowly bifid with a short apical collar of hairs (Norlindh 1943; Goldblatt \& Manning 2000; Herman et al. 2000). In Garuleum, fruits develop from the ray florets only, except in G. bipinnatum, in which the disc florets are bisexual and the fruits that develop from these disc florets are winged, evidently as an adaptation to wind dispersal (Swelankomo 2010). The ray cypselae in this species vary in shape from obpyramidal-triangular with small acute angles to narrowly obovate or conical, and the disc cypselae are flattened and cordate, as in many species of Dimorphotheca Moench.

Garuleum currently includes eight species and two subspecies, all endemic to southern Africa (Merxmüller 1967). Although widespread in southern Africa, Garuleum is absent from Botswana, Swaziland and the Limpopo and North-West Provinces of South Africa (Herman et al. 2000, 2003).

No complete taxonomic revision exists for Garuleum, a situation that is rectified here with a detailed taxonomic treatment of the genus. Lectotypes are designated as required and full descriptions, a key to species, illustrations, and distributions are provided for all the species.

\section{MATERIAL AND METHODS}

Morphological characters in Garuleum were studied from herbarium specimens housed in PRE, NH, GRA and NBG (acronyms after Holmgren et al. 1990). The length of the corolla, length and width of the involucre, length of the style and ovary, number of ray florets (where possible) and length of cypselae were measured

\footnotetext{
*Biosystematics and Collections Division, South African National Biodiversity Institute, Private Bag X101, Pretoria, 0001. E-mail: N.Swelankomo@sanbi.org.za.
}

with the aid of a Bausch \& Lomb StereoZoom ${ }^{\circledR}$ Series microscope. Two cypselae from each taxon (except in $G$. album and $G$. tanacetifolium) were examined by means of a scanning electron microscope (ISI SX 25). All samples were dry and were not chemically treated before being sputter-coated with gold-palladium. Anthers were studied under a dissecting and light microscope (Olympus Vanox-S).

\section{TAXONOMY}

Garuleum Cass. in Bulletin de la Société Philomatique de Paris 1819: 172 (1819); Harv.: 92 (1865); Norl.: 33 (1943); B.Nord.: 375 (1994); P.P.J.Herman et al.: 139 (2000). Type species: Osteospermum caeruleum Jacq. [= G. pinnatifidum (L'Hérit.) DC.], lecto., designated by Pfeiffer: 1411 (1873-1874).

Perennial herbs, shrublets or shrubs, sometimes viscid, scabrid or pilose. Leaves alternate, sessile, pinnatifid or toothed, sometimes pungent. Capitula radiate, solitary or corymbose, terminal, pedunculate. Involucre hemispherical-campanulate. Involucral bracts in 2 or 3 rows, ovate to linear, usually ciliate, sometimes reflexed and sometimes pungent. Receptacle convex, epaleate. Ray florets female, fertile; corolla blue, purple, mauve, white or yellow, lamina linear or oblong, 3-toothed, up to $3 \times$ as long as tube. Style branches linear, sub-acute with stigmatic papillae along margins. Ray cypselae triquetrous or somewhat compressed with entire or crenate angles, glabrous. Pappus absent. Disc florets bisexual or functionally male, yellow; corolla tube sub-campanulate above, with 5 lanceolate lobes, lobes glandular, sometimes hairy on back. Anthers minutely caudate, with ovate apical appendages; endothecial tissue polarized. Style terete, deeply bifurcate with linear lobes, covered with acute papillae to well below point of bifurcation or stigmatic papillae along sides. Disc cypselae (developing only in G. bipinnatum) obovate or obcordate in outline, flattened, marginally winged with thickened rim, glabrous. Pappus absent.

\section{8 spp., southern Africa}

Etymology: although the derivation of the name is not explained by Cassini (1819), it is most likely a corruption of the Latin caeruleus, alluding to the blue ray florets, as suggested by Jackson (1990).

\section{Key to species}

1a Leaves toothed or pinnatifid, divided up to \pm halfway to midrib:

2a Leaves discolorous, white-woolly beneath $\ldots \ldots \ldots \ldots$. ..................................... G. album

$2 \mathrm{~b}$ Leaves not strongly discolorous, green and sparsely pilose to glandular beneath:

3a Involucral bracts sub-biseriate, all \pm equal in length. ... . 2. G. sonchifolium 
3b Involucral bracts 3-seriate, outer much shorter than inner 3. G. latifolium

$1 \mathrm{~b}$ Leaves pinnatisect or pinnate, divided to midrib:

4a Capitula borne on short, inconspicuous peduncles obscured by apical leaves. . . . . . . . . . . . . . tanacetifolium

4b Capitula borne on prominent, sparsely leafy peduncles:

5a. Involucral bracts ovate, apices obtuse to acute; capitula usually solitary; stem very rough with conspicuous glands...................... 5. G. woodii

5b. Involucral bracts narrowly lanceolate, apices acuminate; capitula in loose corymbs:

6a Subshrubs with annual flowering stems from gnarled woody base; disc florets female-fertile, fruit developing from both ray and disc florets ....... 6. G. bipinnatum

6b Shrublets with softly woody stems; disc florets female-sterile:

7a All leaves pinnate; stem minutely glandular; cypselae $3.0-3.5 \mathrm{~mm}$ long .............. . G. pinnatifidum

7b Lower leaves irregularly bipinnatipartite or almost tripinnatipartite; stem glandular-hispid; cypselae $4.0 \mathrm{~mm}$ long . . . . . . . . . . . . . . . .8 G. schinzii.

1. Garuleum album S.Moore in Journal of Botany London 16: 133 (1878); C.Claassen 40: t. 1593 (1970). Type: [Eastern Cape], 'Kaffraria, Shawbury,' 1800' [590 $\mathrm{m}$ ], June [without year], Baur 226 (K000273563ALUKA image!, lecto., designated here; K000273562ALUKA image!, isolecto.). [K000273563 is selected as lectotype as it is the most complete specimen, with associated dissections, and bears Baur's handwritten original collecting label].

Viscid aromatic shrub, 0.6-0.9 m high, abundantly leafy and branched, with white-woolly indumentum especially on abaxial surface of leaves, on peduncles and on involucre. Leaves sessile, alternate, lyrato-pinnatifid, 50-95 mm long, white-woolly on abaxial surface, green and very scabrid above, margin serrate with pungent teeth. Capitula radiate, several clustered towards ends of branchlets, peduncles white-woolly, 15-30 mm long. Involucre campanulate, $10 \times 12-15 \mathrm{~mm}$. Involucral bracts 3 -seriate, imbricate, oblong-linear, apices reflexed, white-woolly abaxially, especially towards apices, outer bracts $5.0-5.5 \mathrm{~mm}$ long, middle bracts $8.5-9.0$ $\mathrm{mm}$ long, inner bracts $12.0-12.5 \mathrm{~mm}$ long. Ray florets \pm 26-37, female-fertile, purplish-blue; corolla limb oblong-elliptic, 9-15 $\times 2.5 \mathrm{~mm}$, somewhat glandular towards base; corolla tube $4-5 \mathrm{~mm}$ long, glandular. Style 8.5-9.0 mm long, swollen at the base, glabrous, cylindric, branched, style branches linear, $\pm 2 \mathrm{~mm}$ long, subacute. Ovary glabrous, obovoid, \pm 3 -angled, $3 \mathrm{~mm}$ long. Mature cypselae not seen. Disc florets functionally male, yellow, 6-7 mm long; lobes narrowly ovate, $1.5 \mathrm{~mm}$ long, somewhat hairy on back. Anthers $3 \mathrm{~mm}$ long, linear, minutely caudate with a small apical, ovate appendage. Style, 8-9 mm long, terete swollen at base; style branches $1 \mathrm{~mm}$ long, narrowly ovate, hairy on outer surface. Ovary narrowly obovate in outline, compressed, narrowly winged, 4-5 mm long, glabrous. Flowering time: August-February. Figure 1A.

Distribution and habitat: Garuleum album is a rangerestricted species known only from a small area between
Lusikisiki and Port St Johns in the Eastern Cape Province (Figure 3), occurring in a densely populated area where it is declining due to ongoing habitat loss and degradation. It is recorded from rocky, dolerite soils on hill-slopes at ca. $600 \mathrm{~m}$.

Diagnosis: Garuleum album is distinguished by the soft, white-woolly indumentum, especially on the undersurface of the lyrato-pinnatifid leaves, the peduncle, and the involucre.

\section{Additional specimens}

EASTERN CAPE.-3129 (Port St Johns): Tabankulu, Qala above the road to Gomo Forest, (-AB), 15 Mar. 1995, Wopula $153(\mathrm{NH})$; 10 miles [16 km] N of Lusikisiki, (-BC), 11 Aug. 1953, Codd 7992 (PRE); Mlengana, between Umtata and Port St Johns, (-CA), Feb. 1896, Flanagan 2532 (PRE); Port St Johns, Mlengana, (-CA), 18 Jan. 1910, Pegler 1569 (PRE); Near the Khoweni Forest, Nkanga location, Libode area, (-CA), 26 Apr. 2006, Styles 3056 (NH).

2. Garuleum sonchifolium (DC.) Norl. in Studies in the Calenduleae 1: 425 (1943) (and cf. p. 30); Hilliard: 518 (1977). Osteospermum sonchifolium DC.: 465 (1838); Harv.: 440 (1865); Type: Eastern Cape, between the Umtata and Umzimvubu Rivers, Drège 5109 (G-DC-microfiche! [PRE—photo.!], holo.; E, K, iso.)

Osteospermum sonchifolium var. subpetiolatum Harv.: 440 (1865), syn. nov. Type: [Eastern Cape], 'Keiskammahoek', Cooper 227 (TCD_ALUKA image!, lecto., designated here; K-ALUKA image!, NH!, PRE!, isolecto. [The TCD collection is more complete and plentiful and includes dissected capitula attached (in the capsule). The specimen also includes a good drawing of a disc floret]. [Syntype: [Eastern Cape], Kreili’s country', Bowker 337 (TCD_digital image!)].

Glandular-pubescent, viscidulous, aromatic, perennial herb, suffrutex or dwarf-shrub, 0.3-1.2 m high. Leaves alternate, sessile, ear clasping at bases, membranous, netted-veined, inciso-pinnatifid; the lobes short, sharply few-toothed, all teeth acuminate. Capitula pedunculate, radiate. Peduncle mostly solitary, rarely in a corymb. Involucre campanulate, 9-10 $\times 3 \mathrm{~mm}$. Involucral bracts sub-biseriate, lanceolate-acuminate, $8.0-10.0 \times 2-3 \mathrm{~mm}$. Ray florets $\pm 15-20$, female, fertile, purple-blue, violetblue, blue; corolla limb oblong-elliptic, 8-10 × $4 \mathrm{~mm}$; corolla tube cylindric, up to $3 \mathrm{~mm}$ long, glandular. Style up to $4 \mathrm{~mm}$ long, linear branched, style branches \pm 2.2 $\mathrm{mm}$ long. Ovary up to $2 \mathrm{~mm}$ long, glabrous, obovate in outline. Disc florets functionally male, yellow; lobes ovate, $0.2 \mathrm{~mm}$ long; corolla limb $5 \mathrm{~mm}$ long. Style 5 $\mathrm{mm}$ long, branched, style branches $0.2 \mathrm{~mm}$ long, linear with pollen sweeping hairs, which cover style below the point of bifurcation, for same length as that of branches. Anthers linear, minutely caudate with ovate apical appendages. Ovary up to $3 \mathrm{~mm}$ long. Cypselae $5.5 \mathrm{~mm}$ long, glabrous, three-angles, obpyramidial, strongly rugose. Flowering time: December- July. Figure 1B, 2 A.

Distribution and habitat: Garuleum sonchifolium occurs in KwaZulu-Natal from around Underberg and Mooi River southwards to Kokstad and Fort Beaufort Division in Eastern Cape, (Figure 4), between altitudes of 450-1 $860 \mathrm{~m}$. G. sonchifolium has been recorded along river banks and on hillsides, mountain slopes and 
ridges, along the road, and along forest margins, on stony soils, rocky outcrops and grassland.

Diagnosis: resembling G. latifolium in its alternate, sessile, membranous leaves, coarsely toothed or more deeply cut halfway to midrib but distinguished by the sub-biseriate vs. 3-seriate involucre.

\section{Additional specimens}

KWAZULU-NATAL.-2929 (Underberg): Lundy's Hill, (-DB), 26 Mar. 1901, Wood 8116 (PRE); Tillietudlem, (-DB), 9 Feb. 1947, Huntley 131 (NH). 2930 (Pietermaritzburg): Mooi River, Warley Common, (-AA), 17 Mar. 1920, Mogg 7179 (PRE); Mooi River, near Mooi River, (-AA), 19 Dec. 1885, Wood PRE 44110 (PRE); Nottingham road, (-AC), Mar. 1939, McClean 922 (PRE); Richmond, Byrne,
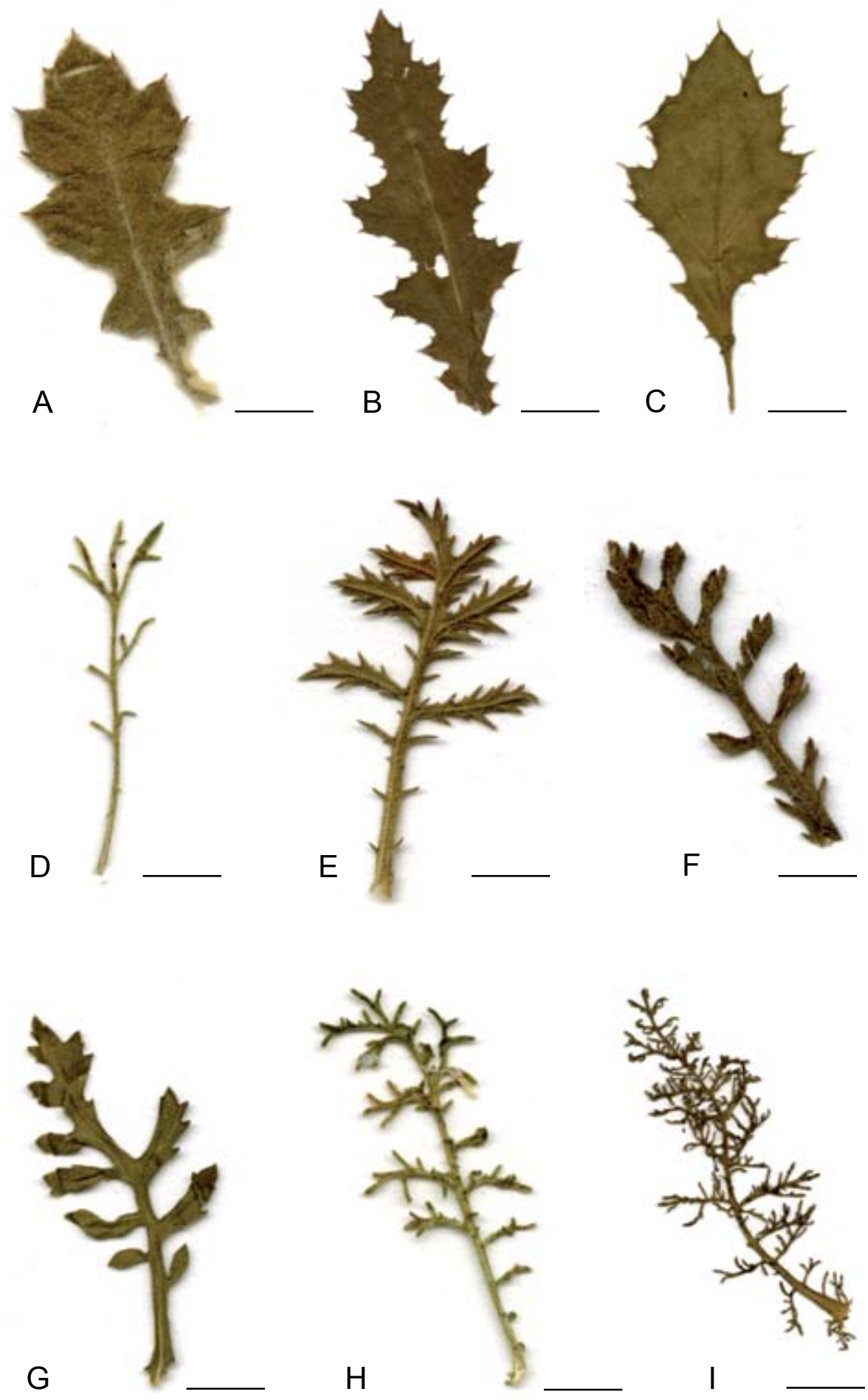

FIGURE 1.-Variation in shape and size of the leaves of Garuleum species. A, G. album, Codd 7992; B, G. sonchifolium, McClean 922; C, G. latifolium, Hitchins 54; D, G. bipinnatum, Esterhuysen 5286; E, G. tanacetifolium, Acocks 16812; F, G. woodii, Devenish 491; G, G. pinnatifidum, Hanekom 908; H, G. schinzii subsp. schinzii, Giess, Volk \& Bleissner 7176 ; I, G. schinzii subsp. crinitum, Mexmüller 826. Scale bars: A-I, $20 \mathrm{~mm}$. 

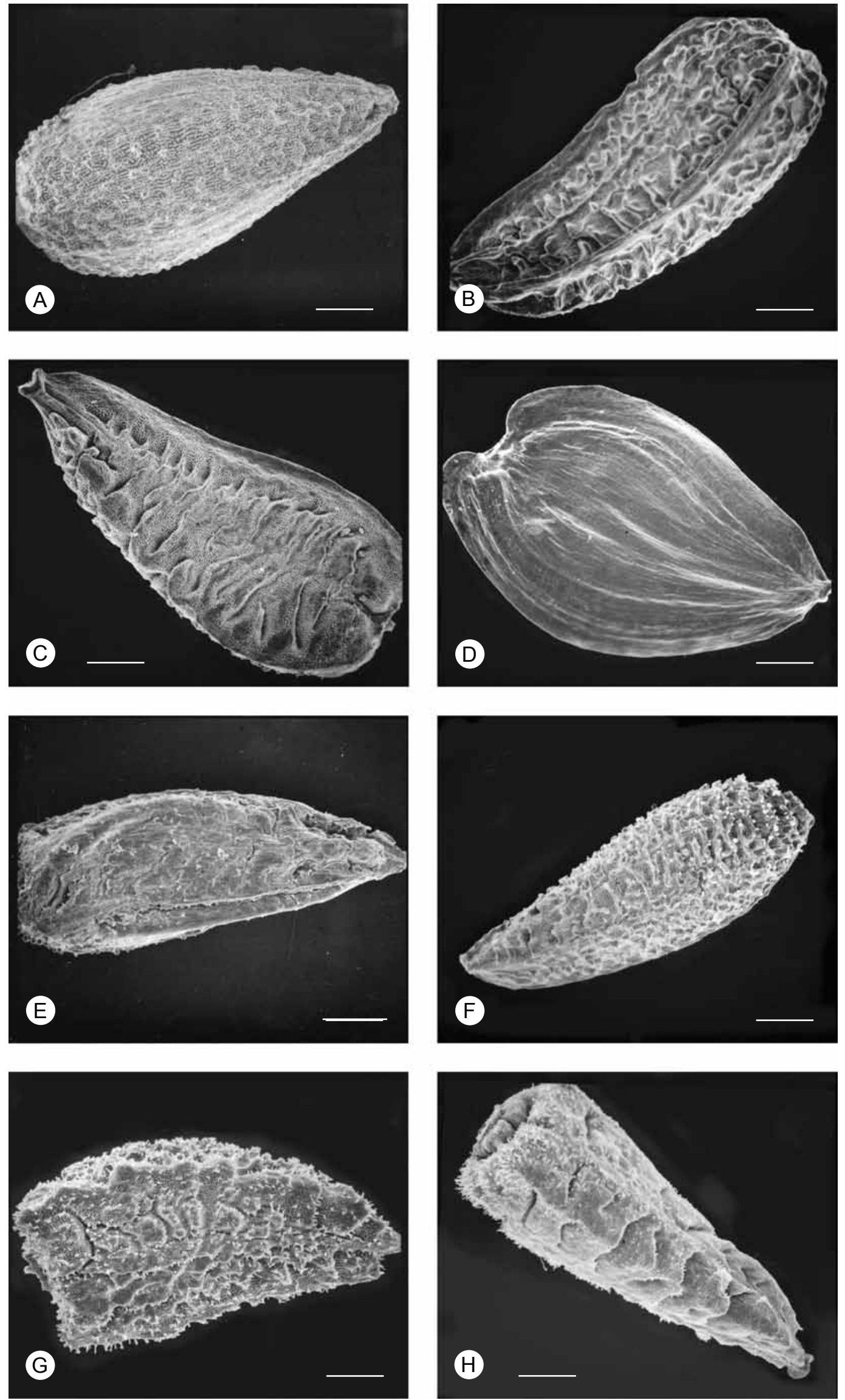

FIGURE 2.-SEM micrographs of the cypselae of Garuleum species. A, G. sonchifolium, Flanagan 599, ray cypsela; B, G. latifolium, Galpin 13374, ray cypsela; C, G. bipinnatum, Rodriguez-Oubina \& Cruces 2107, ray cypsela; D, G. bipinnatum, Rodriguez-Oubina \& Cruces 2107, disc cypsela; E. G.woodii, Jordaan 2763, ray cypsela; F, G. pinnatifidum, Hanekom 1954, ray cypsela; G, G. schinzii subsp. schinzii, Oliver \& Steenkamp 6306, ray cypsela; H, G. schinzii subsp. crinitum, Merxmuller 826, ray cypsela. Scale bars: A, B, E, H, $491.512 \mu \mathrm{m} ; \mathrm{C}, 385.238$ $\mu \mathrm{m} ; \mathrm{D}, \mathrm{G}, 509.065 \mu \mathrm{m} ; \mathrm{F}, 475.128 \mu \mathrm{m}$. 


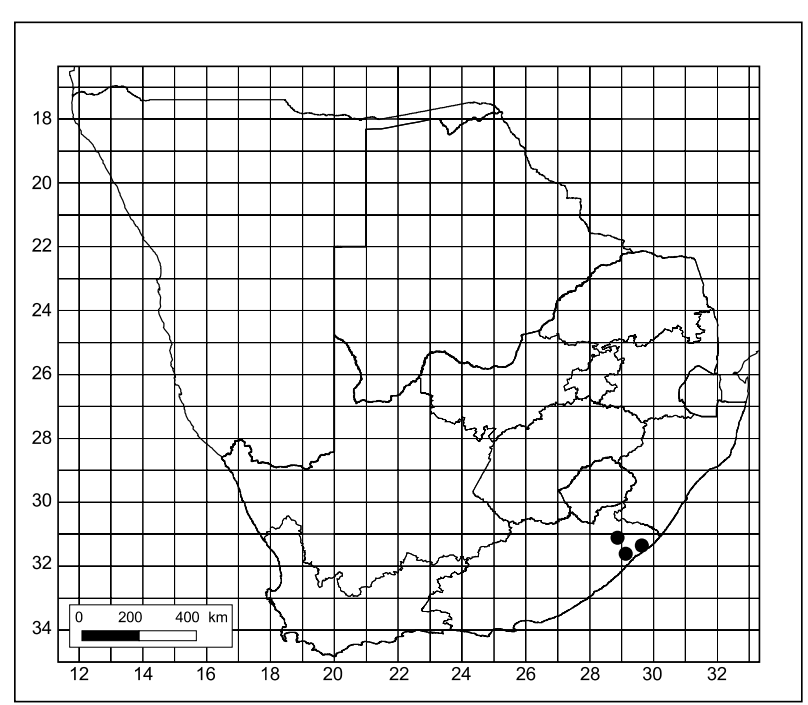

FIGURE 3.-Distribution of Garuleum album.

(-CC), 24 Apr. 1932, Galpin 11913 (PRE). 3029 (Kokstad): Alfred, Weza, Zuurberg, (-BC), 3 Mar. 1974, Hilliard 5465 (PRE); Alfred, Harding, Rooval Farm, (-DB), 2 Mar. 1983, Hilliard \& Burtt 16754 (PRE).

EASTERN CAPE.-3029 (Kokstad): Griqualand East, Malowe Mountain, (-BD), Feb. 1885, Tyson 1047 (PRE). 3129 (Port St Johns): Umtakatyi River, head of Umtakatyi River $\mathrm{N}$ of Libode, $(-\mathrm{CC}), 16$ Sept. 1947, Acocks 13809 (PRE); On road from Tabankulu to Lusikisiki, near the Horseshoe, (-AB), 22 June 1995, Phillipson, Dold \& Cloete 4326 (PRE). 3226 (Fort Beaufort): Stockenstromm, Katberg, (-BC), 1898, Sim 19812 (PRE); Seymour, Hogsback, Auckland Forest, (-DB), 14 Aug. 1943, Giffen 838 (PRE); Amatole Mountains, bottom of Hogsback Pass, (-DB), 13 Aug. 1984, Phillipson 874 (PRE). 3227 (Stutterheim): Keiskammahoek, Keiskamma River, Boma Pass, (-CA), 20 Sept. 1942, Acocks 9098 (PRE); King Williams Town, Pirie, (-CB), 24 Jan. 1936, Taylor 1753 (PRE); Stutterheim, 8.4 miles [13.4 $\mathrm{km}]$ from Stutterheim on Keiskamma Hoek road, $(-\mathrm{CB}), 22$ Sept. 1954, Marais 526 (PRE); Keiskammahoek, 11.5 miles [18.4 km] from Keiskammahoek bridge on road to Debe Nek, (-CC), 18 Mar. 1948, Story 3374 (PRE); Isedenga Forest near King William's Town, (-CD), 9 Mar. 1964, Batten, A.U. 1 Plate 54 (NBG); Komga, Valley near Komga, (-DB), Feb. 1891, Flanagan 599 (PRE). 3228 (Butterworth): Willowvale, Ngqaqini, (-AD), Nov. 1983, Van Eeden $B 369$ (PRE); Kei River near Kei River, (-CA), Flanagan 599A (PRE). 3327 (Peddie): East London, (-BB), 28 Sept. 1909, Rattray 7878 (PRE).

3. Garuleum latifolium Harv. in Flora Capensis 3: 92 (1865); Hilliard: 516 (1977). Type: [Kwazulu-Natal], 'Natal, Tongaat River', Gerrard s.n. K000273564.ALUKA image!, lecto., designated here; TCD0002908 (TCD.-ALUKA image!, isolecto.). [K000273564 was selected as the lectotype over the available syntype, $T C D 0002908$ as it is of better quality and this specimen closely resembles $G$. latifolium compared to the TCD specimen].

Osteospermum calendulaceum Harv. in Flora Capensis 3: 440 (1865), hom. illegit. non L.f. (1782). Type: [KwaZulu-Natal], 'Port Natal' Gueinzius s.n. MEL2357571 (MEL—digital image!, holo.).

Slender, leafy, soft-wooded sub-shrub up to $1.2 \mathrm{~m}$ tall; stem and leaves minutely glandular-pubescent, aromatic. Leaves alternate, membranous, sessile or sometimes narrowed to a petiole-like base often with a pair of stipule-like basal auricles, up to $60 \times 30 \mathrm{~mm}$, oblanceolate or oblong in outline, coarsely toothed or more

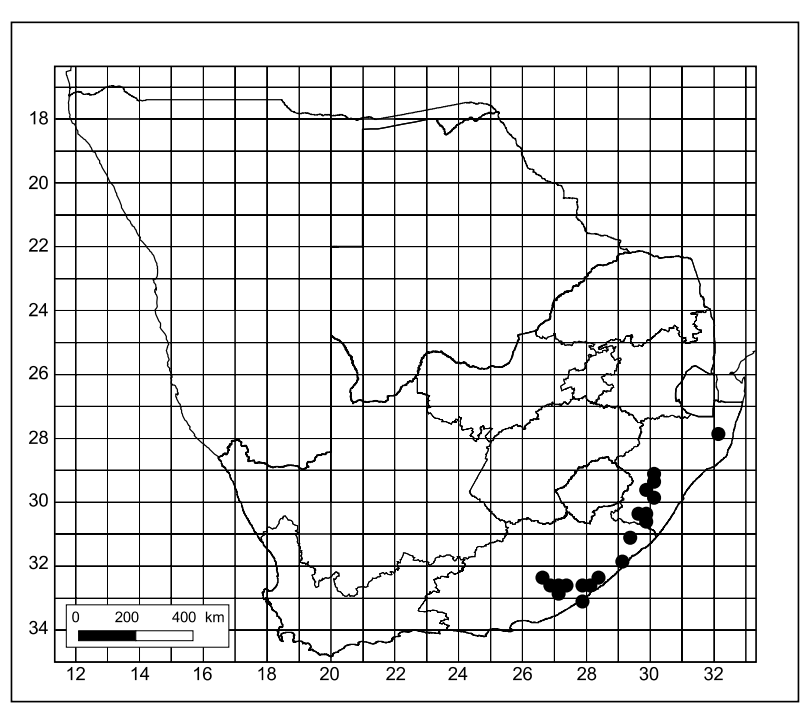

FIGURE 4.-Distribution of Garuleum sonchifolium.

deeply cut halfway to midrib, lobes toothed, teeth subulate. Capitula radiate, pedunculate. Peduncles up to $15 \mathrm{~mm}$ long arranged in lax terminal corymbs. Involucre and upper part of peduncle loosely woolly at first, later glandular-hispid. Involucre campanulate. Involucral bracts in 3 rows, imbricate, ovate-linear, pungent, outer $2.5-3.0 \times 1.5 \mathrm{~mm}$, inner $8.5-9.0 \times 1.1 \mathrm{~mm}$. Ray florets numerous, female, fertile, $\pm 10 \mathrm{~mm}$ long, blue or white; corolla limb up to $6 \mathrm{~mm}$ long; corolla tube up to $4 \mathrm{~mm}$ long, glandular. Style up to $4 \mathrm{~mm}$ long, branched, linear, style branches $2 \mathrm{~mm}$ long, subacute. Ovary up to $1.8 \mathrm{~mm}$ long, glabrous, obovate in outline, angled. Disc florets functionally male, yellow; the corolla limb 3.0 $3.5 \mathrm{~mm}$ long, glandular, 5-lobed; the lobes ovate $0.2 \mathrm{~mm}$ long; lower part of corolla $1 \mathrm{~mm}$ long. Anthers linear, minutely caudate, with an ovate apical appendage. Style up to $5 \mathrm{~mm}$ long, branched, linear, style branches 0.1 $\mathrm{mm}$ long with stigmatic papillae along margins. Ovary $2 \mathrm{~mm}$ long. Cypselae 4-5 $\mathrm{mm}$ long, glabrous, narrowly obovate, somewhat 3-angled, obscurely winged, strongly transversely wrinkled and warty, reddishbrown. Flowering time: February-July. Figure 1C, 2B.

Distribution and habitat: Garuleum latifolium is recorded from the Lebombo Mountain in the north, down to Pietermaritzburg in Inanda District, (Figure 5), up to $656 \mathrm{~m}$. It grows in sandy-loam soil, outcrops, on the margins of bush clumps, Natal Group Sandstone.

Diagnosis: resembling G. sonchifolium in the alternate, membranous, coarsely toothed or more deeply cut leaves, but distinguished by the involucral bracts in 3 series, ovate-linear, with the outer bracts much shorter than the inner.

Hilliard (1977) synonymised Osteospermum calendulaceum under Garuleum latifolium.

\section{Additional specimens}

KWAZULU-NATAL. $\mathbf{2 7 3 2}$ (Ubombo): Mkuze, top of Mtn, (CA), 27 Aug. 1932, Galpin 13374 (PRE); Hlabisa, Makhowe, (-CC), 29 May 1971, Lavranos 8690 (PRE). 2831 (Nkandla): Mhlabatini, Townlands, (-AB), 1 May 1942, Gerstner 4669 (PRE, NBG). 2832 


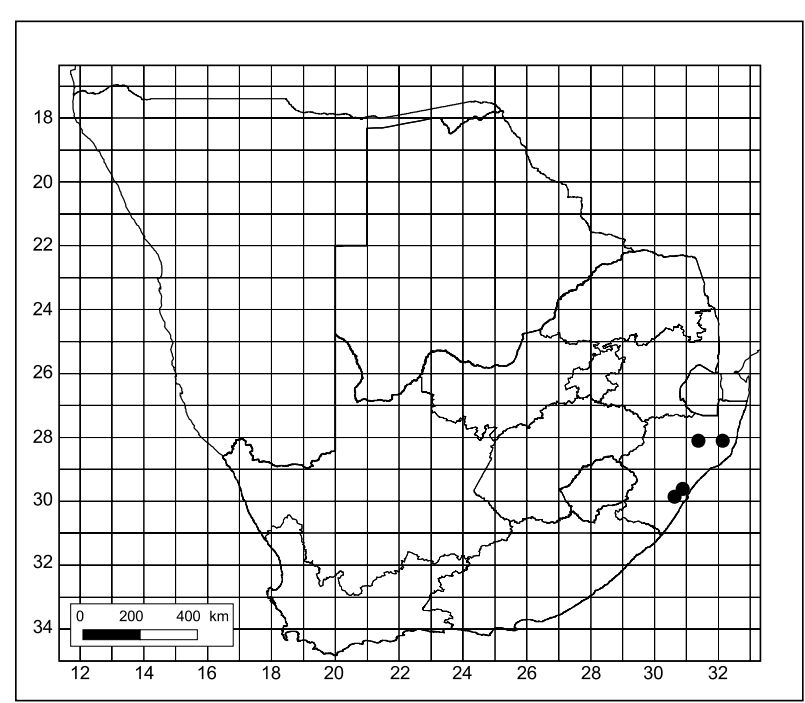

FIGURE 5.-Distribution of Garuleum latifolium.

(Matubatuba): Hlabisa, Hluhluwe Game Reserve, (-AA), 20 July 1961, Hitchins 54 (PRE). 2930 (Pietermaritzburg): Greater Durban Metropolitan Area, Hammarsdale area, Hector (ESKOM) Substation Site, (-DC), 29 Mar. 1995, Ward 12972 (PRE); Inanda, (-DB), Nov. 1883 , Wood 160 (PRE).

4. Garuleum tanacetifolium (MacOwan) Norl. in Studies in the Calenduleae 1: 30 (1943). Osteospermum tanacetifolium MacOwan: t. 1839 (1889). Type: [Eastern Cape], 'Kagaberg and Boschberg', MacOwan 1382 (GRA-ALUKA image!, holo.; K-ALUKA image!, PRE!, iso.).

Shrub with simple and leafless stem at the base, branched above. Leaves alternate, scabrid-glandular, sessile, very densely crowded at ends of branches, recurved-spreading, interruptedly bipinnatipartite with sharply incised lobes, and pectinate rachis on both sides. Capitula radiate, solitary, shortly pedunculate. Involucre campanulate, $10 \mathrm{~mm}$ in diam. Involucral bracts in 2-series, more-or-less equal, oblong, slightly acute with membranous margins; outer $\pm 7.0 \mathrm{~mm}$ long; inner \pm 7.5 $\mathrm{mm}$ long. Ray florets (10-)12, female, fertile, dark purple, mauve, pale lilac or white, oblong-elliptic; corolla limb 12.0-12.5 mm long, narrowly linear; corolla tube up to $4 \mathrm{~mm}$ long, glandular. Style up to $5.5 \mathrm{~mm}$ long, linear, branched, style branches $\pm 2 \mathrm{~mm}$ long. Ovary up to $2.2 \mathrm{~mm}$ long, glabrous, obovate in outline. Mature cypselae not seen. Disc florets functionally male, yellow, 5-lobed; lobes ovate, $0.2 \mathrm{~mm}$ long; corolla limb 2.5-3.0 $\mathrm{mm}$ long, glandular; corolla tube $1.2 \mathrm{~mm}$ long, glandular. Style 3.0-3.2 mm long, branched, style branches \pm $1 \mathrm{~mm}$ long, linear with pollen sweeping hairs. Anthers linear, minutely caudate, with ovate apical appendages. Ovary up to $2.5 \mathrm{~mm}$ long. Flowering time: May to June. Figure 1E.

Distribution and habitat: Garuleum tanacetifolium is endemic to the Sneeuberg Centre of Endemism, (Figure 6), 1200 to $1800 \mathrm{~m}$. It was found along edges of forests and on mountain ridges, abundant on sandstone soils. Until now Garuleum tanacetifolium was known from just two collections on the Boschberg and was treated as DDT (Data Deficient-Taxonomically problematic) in conservation assessments (Raimondo et al. 2009).

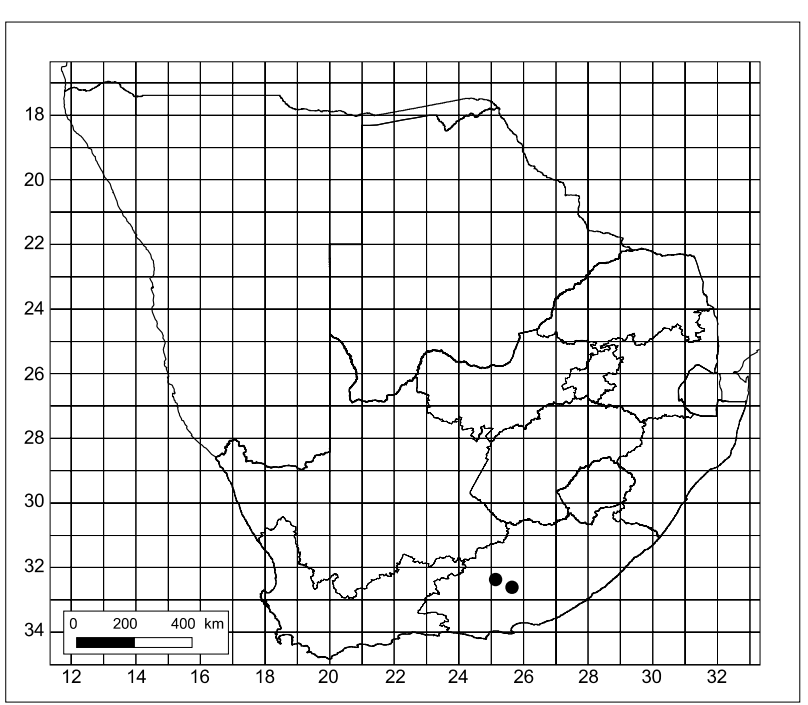

FIGURE 6.-Distribution of Garuleum tanacetifolium.

Recent collections by R. Clark, during field work for a checklist of Boschberg, have shown that the species is in fact abundant in the Nardousberg area of the Sneeuberg, certain south-facing slopes above $1600 \mathrm{~m}$, and occurs locally on the Boschberg in montane fynbos. It also apparently occurs on the Great Winterberg-Amatolas but has not been collected from there (R. Clark pers. comm., January 2013).

Diagnosis: Garuleum tanacetifolium is distinguished from other species by recurved-spreading, bipinnatipartite leaves with sharply incised, pectinate lobes, and heads borne on a short, inconspicuous peduncle.

\section{Additional specimens}

EASTERN CAPE.-3225 (Somerset East); Sneeuberg, Asante Sana Private Game Reserve, on the mountains behind old town of Petersburg (-AC), 6 Oct. 2008, Clark \& Coombs 703, (GRA, NBG); Boschberg, edge of forest, (-DA), 1 May 1953, Acocks 16812 (PRE); Boschberg Nature Reserve, upper slopes of Boschberg along path, in forest, (-DA), 5 Dec. 2008, Clark, Daniels, Fabricus \& le Roux 243 (GRA); Groot-Bruintjieshoogte, Labuschagne's Kraal, 57 Farm, summit, (-CB), 11 Dec. 2008, Clark, Daniels, Fabricus \& le Roux 452 (GRA).

5. Garuleum woodii Schinz in Bulletin de L'Herbier Boissier 3: 440 (1895); Hilliard 518 (1977). Type: [KwaZulu-Natal], valley of Buffalo River near Charlestown, [1 525-1 830 m], 6 Dec. 1892, Wood 4840 (Z, lecto., designated here; BOL, K, PRE!, isolecto.). [Wood 4840 was selected as the lectotype over the available syntype, Wood 4496 as it is of better quality.]

Viscid, aromatic, well-branched shrublet, up to 600 $\mathrm{mm}$ high; stems and leaves rough with glandular hairs. Leaves sessile, alternate, oblong in outline, up to $50 \times 20$ $\mathrm{mm}$, once or twice pinnatisect, the segments very narrow, sometimes lobulate, sub-acute, base half-clasping. Capitula solitary, showy, on long remotely leafy or bracteate peduncles terminating upper branches. Involucre campanulate. Involucral bracts in \pm 4 series, imbricate; outer shorter 3.5-4.0 $\mathrm{mm}$ long; middle up to $5 \mathrm{~mm}$ long; inner 5.5-6.0 mm long, all ovate, gland-dotted, apices obtuse to acute. Ray florets female, fertile, blue or white; corolla limb 6.5-7.0 × $2 \mathrm{~mm}$, oblong-elliptic; corolla 


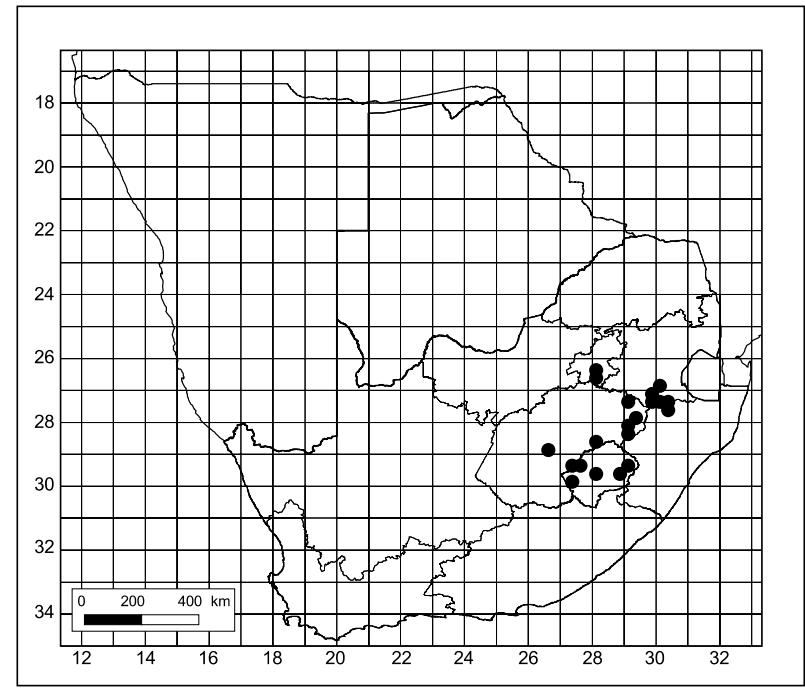

FIGURE 7.-Distribution of Garuleum woodii.

tube up to $2.8 \mathrm{~mm}$ long, glandular, cylindric. Style up to $2.8 \mathrm{~mm}$ long, branched, linear, style branches 2.2 $\mathrm{mm}$ long. Ovary up to $2 \mathrm{~mm}$ long, glabrous, obovate in outline. Disc florets functionally male, yellow, 5-lobed; lobes ovate, $0.2 \mathrm{~mm}$ long; corolla limb glandular, 2.5 $3.0 \mathrm{~mm}$ long; corolla tube $1 \mathrm{~mm}$ long, glandular. Style 4.0-4.5 mm long, branched, style branches $0.2 \mathrm{~mm}$ long, linear with pollen sweeping hairs, which cover style below point of bifurcation. Anthers linear, minutely caudate, with ovate apical appendages. Ovary up to $2.5 \mathrm{~mm}$ long. Cypselae $\pm 6 \mathrm{~mm}$ long, glabrous, narrowly obovate, somewhat 3-angled, obscurely winged, obscurely transversely wrinkled, light yellowing-brown. Flowering time: January-May. Figure 1F, 2E.

Diagnosis: distinguished from other species by the stem and leaves that are rough with glandular hairs, and ovate involucral bracts.

Distribution and habitat: Garuleum woodii is recorded from Lesotho to Ficksburg and Platberg outside Harrismith, northwards along the Drakensberg to Wakkerstroom, and inland to Suikerbosrand Nature Reserve in Gauteng, (Figure 7), 1 645-2 745 m. It occurs on hillsides and mountain slopes along streams and rivers, on cliff faces and along roads and ridges, on sandstone or clay soils in stony or rocky situations.

\section{Additional specimens}

GAUTENG. - 2628 (Johannesburg): Klipriviersberg, S of Rosettenville, (-AC), 8 Apr. 1945, Wasserfall 912 (PRE); Suikerbosrand Nature Reserve, Kareekloof, (-CA), 16 Oct. 1971, Bredenkamp 154 (PRE).

MPUMALANGA.-2630 (Carolina): Kalkoenkrantz, Elandsberg Farm, (-CC), 6 Nov. 1984, Turner 342 (PRE). 2729 (Volksrust) Ermelo, Amersfoort, Maquiabe Farm of Koos Wessels, (-BB), 8 Jan. 2000, Siebert \& Du Plessis 1225 (PRE); Amersfoort, Sterkfontein Farm, (-BB), 30 Mar. 1987, Turner 1597 (PRE); Volksrust Highlands, (-BD), 7 May 1920, Mogg 7504 (PRE). 2730 (Vryheid): Wakkerstroom, (-AC), Feb. 1917, Beeton HWB 204 (PRE); Wakkerstroom, Tafelkop Farm, (-AC), 3 Feb. 1994, Jordaan 2763 (PRE).

KWAZULU-NATAL. $\mathbf{2 7 2 9}$ (Volksrust): Charlestown, near Charlestown, (-BD), 25 Feb. 1895, Wood 5542 (PRE); Charlestown, near Charlestown, (-BD), 10 Jan. 1894, Wood 5185 (NH). 2730 (Vryheid): Utrecht, Naauwhoek, (-AD), 19 Jan. 1961, Devenish 491 (PRE);
Wakkerstroom, Oshoek Farm, on edge of escarpment, (-AD), 21 Feb. 1978, Smook 1209 (PRE).

FREE STATE.-2729 (Volksrust): Vrede, Berlin Farm, at Slang River en route to ascent $16 \mathrm{~km} \mathrm{NW}$ of Vrede, $(-\mathrm{AC}), 12$ Mar. 1991, Eckhardt 12 (PRE); Driekoppe Darm; $42 \mathrm{~km} \mathrm{SE} \mathrm{of} \mathrm{Vrede} \mathrm{on} \mathrm{road} \mathrm{to}$ Verkykerskop, base of Aasvoëlkop, beginning of kloof, (-CD), 4 Feb. 1987, Retief 1987 (PRE); Verkykerskop, Nonpareil Farm, at foot of hill, (-CD), 14 Mar. 1990, Saaiman 664 (PRE). 2826 (Brandfort): Near Roodepoort boundary, Syferfontein Farm, \pm 2 miles [3.2 km] SSW of Greylingstad on road to Rooiwal and Leeuwspruit, northwestern slopes of koppie, (-DC), 20 Mar. 1967, Scheepers 1591 (PRE). 2828 (Bethlehem): Ficksburg, Moolman's Hoek Peak, summit of peak, (-CA), 30 Oct. 1934, Galpin 13924 (PRE). 2829 (Harrismith): Loskop, (AA), 18 Mar. 1970, Stam 420 (PRE); Platberg, (-AC), 14 Dec. 1976, Jacobsz 3054 (PRE); Platberg, (-AC), 8 Sept. 1983, Roux 1262 (PRE, NBG); Platberg, One Man Pass, (-AC), 13 Dec. 1976, Hilliard \& Burtt 9507 (PRE); Harrismith, (-AC), Dec. 1912, Thode 2895 (PRE).

LESOTHO.-2927 (Maseru): E of Maseru, (-AD), 25 Oct. 1963, Cooley \& Kofler 10926 (PRE); Makheka, Roma Valley, on top of Makheka, (-BC), Sept. 1974, Schmitz 4190 (PRE); Mafeteng, Thaba Tsoeu, (-CD), 10 Mar. 1917, Dieterlen 1273 (PRE). 2928 (Marakabeis): Monia Hania, hillslope, (-CA), 10 Jan. 1954, Jacot-Guillarmod 1711 (PRE); Orange River Valley, $26 \mathrm{~km}$ from Taung between Mashai and Sehonghong, (-DB), 1 Dec. 1977, Killick 4294 (PRE). 2929 (Underberg): Mokhotlong, (-AC), Mar. 1949, Jacot-Guillarmod 1136 (PRE); Mokhotlong, (-AC), 27 Feb. 1949, Compton 21539 (PRE, NBG).

6. Garuleum bipinnatum (Thunb.) Less., Synopsis generum compositarum: 194 (1832); DC.: 309 (1836); Harv.: 92 (1865); Norl.: 377 (1977). Osteospermum bipinnatum Thunb: 167 (1800); Thunb.: 717 (1825); Juel: 717 (1918). Type: [Northern Cape], Hantam, Thunberg s.n. UPS-THUNB20814 (UPS-THUNB-microfiche!, holo.).

Dimorphotheca multifida DC.: 73 (1838); Harv.: 422 (1865). Type: [Eastern Cape], 'Albany', Ecklon \& Zeyher (G-DC - microfiche!, lecto., designated by Norlindh: 378 (1977).

Aromatic, viscid, subshrub, 0.6-1.5 m tall. Stems arising from woody rootstock, up to $3 \mathrm{~cm}$ in diam., erect, usually branched, striate or slightly furrowed, glandular. Leaves alternate, glandular, about 10-40 $\mathrm{mm}$ long, bipinnatipartite. Capitula radiate, pedunculate, solitary at ends of stem and branches or arranged in loose corymbs. Peduncles vary greatly in length, up to $120 \mathrm{~mm}$ long, and have a few small, dentate or entire bracts. Involucre campanulate $5-8 \mathrm{~mm}$ high, $\pm 10 \mathrm{~mm}$ broad when pressed. Involucral bracts in 2 or 3 series, imbricate, \pm glandular, outer bracts narrowly lanceolate, $\pm 3.0-4.0 \mathrm{~mm}$ long, inner bracts narrowly oblonglanceolate, $\pm 5.0-6.0 \mathrm{~mm}$ long, with whitish-scarious margins and often violet tips. Ray florets female, fertile, strap shaped, varying a lot in colour, including white, blue, mauve, purple and violet, and are about as long as involucres; corolla limb up to $10-15 \times 3 \mathrm{~mm}$, elliptic; corolla tube up to $3 \mathrm{~mm}$ long, glandular, cylindric. Style up to $3 \mathrm{~mm}$ long, branched, linear, style branches $2 \mathrm{~mm}$ long, subacute. Ovary up to $2.1 \mathrm{~mm}$ long, glabrous, obovate in outline, angled. Cypselae: compressed triangularobpyramidal, $\pm 4.0-5.0 \mathrm{~mm}$ long, glabrous. Disc florets bisexual, yellow and about same size as involucres; corolla limb $3 \mathrm{~mm}$ long, widening upwards, glandular, 5-lobed; lobes ovate, $0.2 \mathrm{~mm}$ long; lower part of corolla tubular, $1.8 \mathrm{~mm}$ long, glandular. Style up to $5 \mathrm{~mm}$ long, branched, curved, bulbous at the base, style branches 2.5 $\mathrm{mm}$ long with stigmatic papillae along sides. Anthers 2 


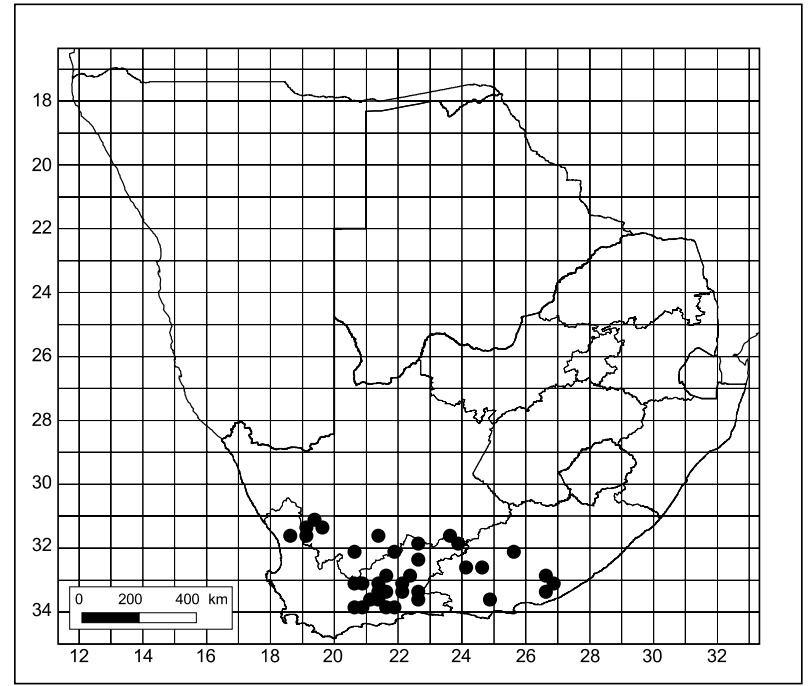

FIGURE 8-Distribution of Garuleum bipinnatum.

$\mathrm{mm}$ long, linear, with an ovate apical appendage, caudate. Ovary $3 \mathrm{~mm}$ long. Cypselae: outer fertile, obovate and slightly emarginate at the tip or almost obcordate, marginal wing with stiff, thickened margin, up to $5.0 \times$ $3.5 \mathrm{~mm}$, inner sterile narrowly obovate, 5-6 $62 \mathrm{~mm}$, pellucid. Flowering time: throughout the year. Figure 1D, $2 \mathrm{C}, 6$.

Distribution and habitat: Garuleum bipinnatum occurs from Fort Beaufort Division in Eastern Cape westwards through the Little Karoo to Montagu in Western Cape and Vanrhynsdorp in Northern Cape (Figure 8 ), at altitudes of 305-1 $220 \mathrm{~m}$. The species grows in various substrates and habitats, including dolerite rocks, clay soil, shale soil, stony sandy loam soil, stony loam soil, sandy clay gravel on shale soil, on dry stony koppies [hillocks], mountain slopes and rocky outcrops, in dry stream-beds, on floodplains, Karoo plains and river banks, in xeric succulent thicket, false macchia, spekboom veld and broken karroid veld.

This species is palatable to livestock and is aromatic. The flowers have a range of colours from white to blue, mauve, purple and violet and has horticultural potential as it is easily cultivated (Swelankomo 2010). The roots were used as snake bite remedy among early settlers. Farmers have also used a decoction or a tincture of it in various diseases of the chest, and in the Cape the root has been used in preparing a mouth wash (Watt \& Breyer-Brandwijk 1962).

Diagnosis: Garuleum bipinnatum is the only species where both ray and outer disc florets develop fertile cypselae; the leaves are twice-pinnate, decreasing in size and degree of lobing towards the inflorescence; inner bracts have whitish-scarious margins and often violet tips, and the plant is glabrous. It can be easily confused with Garuleum schinzii, but in G. schinzii the fruits develop from ray florets only, and the plant is glandularhispid.

\section{Additional specimens}

NORTHERN CAPE.-3118 (Vanrhynsdorp): Vanrhynsdorp, (DA), 25 July 1941, Esterhuysen 5286 (PRE). 3119 (Calvinia): Koker- boomkop, (-AB), 24 Aug. 1926, Acocks 18969 (PRE); Vanrhynsdorp, Van Rhyns Pass, (-AC), 25 July 1941, Compton 11124 (PRE); Nieuwoudtville Reserve, (-AC) 25 July 1983, Perry \& Snijman 2171 (PRE); Vanrhynsdorp, Van Rhyns Pass, (-AC), 25 July 1941, Esterhuysen 5286 (PRE); Hantam Mountains, (-BC), Thunberg PRE 44089 (PRE); Niewoudtville Wildflower Reserve, W-facing hill at circle route hiking trail, (-AC), 3 Sept. 2007, Hitchcock, Cowell \& Bennett MSBP 3418 (NBG); Vanrhynsdorp, halfway down Vanrhyn's Pass, (AC), 8 Sept. 2006, Helme 4250 (NBG). 3220 (Sutherland): $17 \mathrm{~km} \mathrm{~N}$ of Matjiesfontein next to national road, (-BA), 13 Mar. 1981, Van Wyk 513 (PRE). 3221 (Merweville): Fraserburg, Layton, Springbok camp, (-BB), 20 June 1985, Shearing 1033 (PRE).

WESTERN CAPE. - $\mathbf{3 1 2 3}$ (Victoria West): Richmond, $36 \mathrm{~km}$ from Richmond to Beaufort West, on N1 road near Rietfontein West, (-DA), 28 Aug. 1995, Rodriguez-Oubina \& Cruces 2115 (PRE); Murraysburg, (-DD), Dugmore 2060 (PRE). 3221 (Merweville): Fraserburg, Layton, Eselrand, SE of mountain, (-BB), 28 May 1967, Shearing 89 (PRE); Prince Albert, $10 \mathrm{~km}$ beyond Prince Albert road on road to Merweville, (-DC), 7 Dec. 1976, Venter 1430 (PRE). 3222 (Beaufort West): Bulwater P.O.; 20 miles [32 km] NW of Bulwater P.O., (-BC), 17 Mar. 1948, Acocks 14148 (PRE); Karoo National Park, (-BC), 6 Sept. 1983, Braack 63 (PRE); Prince Albert, Klein-Waterval farm, $\pm 2 \mathrm{~km}$ before farmhouse on road from Seekoegat, $(-C D), 7$ Oct. 1983, Retief \& Reid 193 (PRE). 3320 (Montagu): Laingsburg, Whitehill ridge, (BA), 20 Sept. 1943, Compton 14904 (PRE); Josephskraal, (-BA), 7 July 1966, Van Breda 2127 (PRE); $17 \mathrm{~km} \mathrm{~N}$ of Matjiesfontein next to national road, (-BA), 13 Mar. 1981, Van Wyk 513 (NBG); Laingsburg, $7 \mathrm{~km}$ from Matjiesfontein on N1 road to Laingsburg, (-BB), 27 Aug. 1995, Rodriguez-Oubina \& Cruces 2107 (PRE); Swellendam, Barrydale near Barrydale at Meintjes Kraal, (-DC), Sept. 1913, Muir 1037 (PRE); Swellendam, Barrydale, Meinjieskraal, (-DC), 20 Sept. 1913, Muir 9426 (PRE); Warmwatersberg, 1 mile [1.6 km] NE of Warmwatersberg Hot Springs, (-DD), 29 June 1948, Acocks 14564 (PRE). 3321 (Ladismith): Laingsburg, (-AB), 24 Jan. 1941, Esterhuysen PRE 44105 (PRE); Seweweekspoort to Laingsburg near Vleiland farm, (AC), 25 Sept. 2004, Goldblatt \& Porter 12560 (NBG); Prince Albert, Bosluiskloof, between 7 Weeks Poort \& Prince Albert, (-AD), 16 July 1954, Lewis SAM 68695 (PRE); Laingsburg, Bosluiskloof Pass, (-BC), 14 Sept. 1955, Leistner 246 (PRE); Karoo South, Gamkapoort Nature Reserve, Witpoort, (-BC), 4 Nov. 1982, Cattell \& Cattell 220 (PRE); Rietfontein Farm, $\mathrm{N}$ slope of hill $2.4 \mathrm{~km} \mathrm{~S}$ of barn taking right turn just before second gate, (-CA), 26 Aug. 1982, Laidler 339 (PRE, NBG); Little Karoo, Noukloof Nature Reserve, $1.9 \mathrm{~km}$ from dam on circular drive, (-CA), 6 July 1982, Laidler 59 (PRE, NBG); Ladismith, (-CB), 22 Mar. 1976, Hugo 193 (PRE, NBG); Oudtshoorn, Gamka Mountain Reservoir, (-CB), 17 May 1982, Cattell \& Cattell 19 (PRE); George, Gouritzrivier; (-DC), Dec., Ecklon \& Zeyher 232 (PRE); Little Karoo, Kleinfontein Farm, mid-slope 30 miles [48 km] N of road near top of small pass, (-DD), 8 Aug. 1984, Laidler 576 (PRE). 3322 (Oudtshoorn): Prince Albert, (-AA), Sept. 1921, Marloth 10588 (PRE); Prince Albert Road, (-AA), June 1921, Marloth 10142 (PRE); Prince Albert in hills, (-AA), Dec. 1905, Bolus 11525 (PRE); Prince Albert near cemetery to Weltevrede hill $\mathrm{N}$ of road, (-AA), 5 July 1975 , Wisura 3396 (NBG); Swartberg Pass, (-AC), Dec. 1943, Stokoe PRE 44094 (PRE); De Rust; P.M.K. le Roux's Farm, 3 miles [4.8 km] E of De Rust, (-DA), 19 Oct. 1970, Dahlstrand, 1461 (PRE).

EASTERN CAPE.-3224 (Graaff-Reinet): Aberdeen, S of Arberdeen, (-CA), Mar. 1929, Dyer 1940 (PRE); Kendrew, (-DA), Mar. 1929, Dyer 1953 (PRE); between Graaff-Reinet and Jansenville, \pm 50 $\mathrm{km}$ N of Jansenville, (-DA), 1 June 2005, Meyer 4451 (PRE); GraaffReinet, (-DA), 15 Mar. 1930, Galpin 1151 (PRE); Jansenville, (-DC), 5 Dec. 1947, Compton 20320 (NBG). 3225 (Somerset East): Cradock, Cradock Mountains, (-BA), 19 Nov. 1953, Henrici 4575 (PRE). 3226 (Fort Beaufort): between Fort Beaufort \& Grahamstown, (-DC), 18 July 2001, Koekemoer 2077 (PRE); Fort Beaufort, (-DC), 21 Feb. 1938, Britten 6632 (PRE). 3326 (Grahamstown): Albany, Fish River, between Breakfast Vlei \& Grahamstown, (-BB), 1 May 1955, Lewis SAM 68531 (PRE); Albany, (-BC), May 1928, Dyer 1536 (PRE).

7. Garuleum pinnatifidum (L'Hérit.) DC., Prodromus 5: 309 (1836); Harv.: 92 (1865). Osteospermum pinnatifidum L'Hér.: 11 (1785); Thunb.: 167 (1800); Thunb.: 717 (1825). G. viscosum Cass.: 172 (1819), nom. illegit. pro O pinnatifidum L'Hér. Type: 'Cap. Bonae Spei', without precise locality or collector (G-DC-microfiche!, lecto., designated here). [L'Héritier's herbarium was acquired by A.P. de Can- 


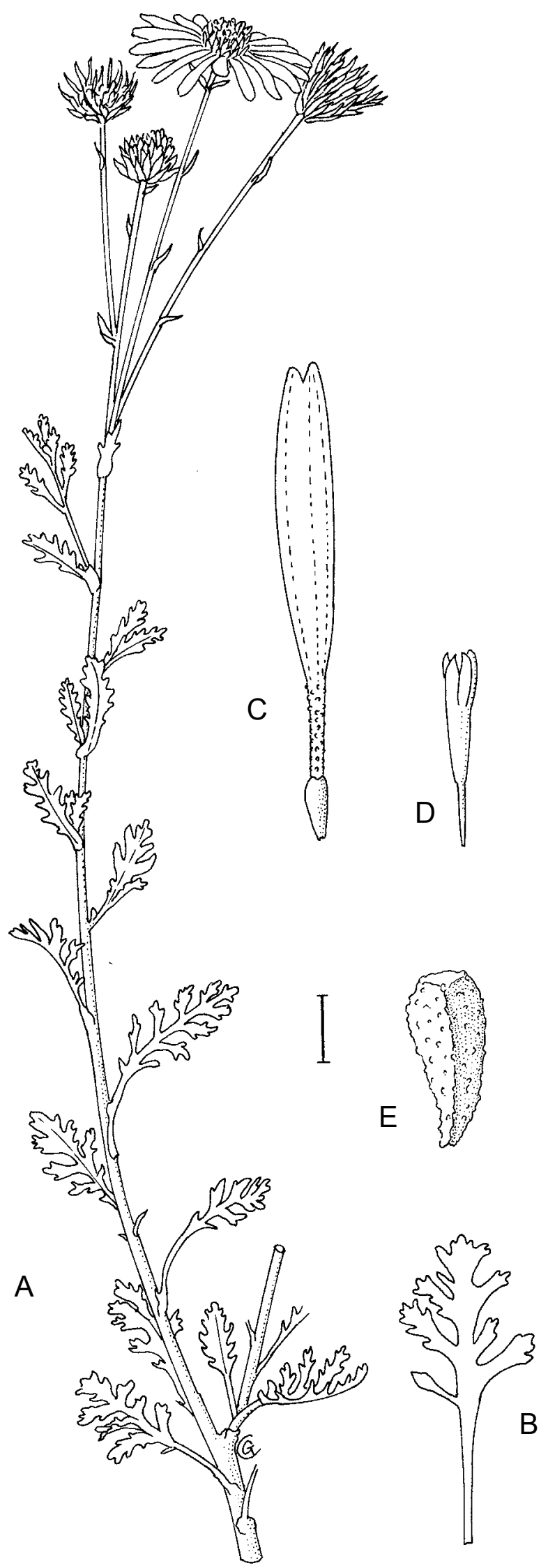




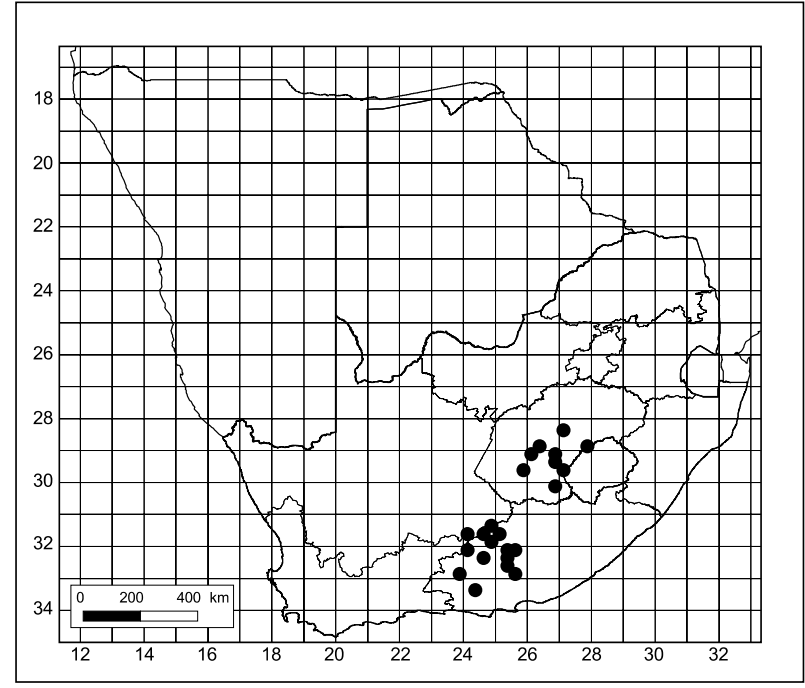

FIGURE 10.-Distribution of Garuleum pinnatifidum.

dolle after his death (Stafleu \& Cowan 1981). Of the four specimens labeled $O$. pinnatifidum in De Candolle's herbarium, the two left hand specimens are from L'Héritier's herbarium: the first bears a label to that effect and the second the appropriate locality label. Both are thus syntypes. We designate the right hand specimen as lectotype as it bears the correct locality label, is the most complete, and closely matches the illustration of the species published by L'Héritier (1785) in the protologue.

Osteospermum caeruleum Jacq.: 78 (1786); Aiton: 275 (1789); Harv.: 92 (1865) [as O. coeruleum Aiton]. Lecto: Illustration in Jacq. Icones plantatum rariorum 1: plate 179 (1781-1786), designated here.

Aromatic, viscid, much branched shrub, 0.3-1.5 m tall. Stem thick, terete, leafy throughout, dividing into flower-bearing peduncles above. Leaves alternate, sessile, pinnate, minutely villous and ciliate $\pm 50 \mathrm{~mm}$ long; pinnae oblong, irregularly serrate, somewhat obtuse, diminishing in size. Capitula radiate, pedunculate. Peduncle solitary. Involucre campanulate, up to $10 \mathrm{~mm}$ long. Involucral bracts in 2-series, more-or-less equal, thick, acute; outer 3.5-4.0 × $1 \mathrm{~mm}$; inner 4.0-5.0 $\times 1$ $\mathrm{mm}$. Ray florets \pm 18 , female, fertile, strap-shaped, blue, mauve; corolla limb up to $9 \times 3 \mathrm{~mm}$, elliptic; corolla tube 2.8-3.0 mm long, glandular, cylindric. Style up to 3 $\mathrm{mm}$ long, linear, branched, style branches $2.2 \mathrm{~mm}$ long, sub-acute. Ovary up to $2.1 \mathrm{~mm}$ long, glabrous, obovate in outline. Disc florets functionally male, yellow, 5-lobed; lobes ovate, $0.2 \mathrm{~mm}$ long; corolla tube very hairy. Style 3.5-4.0 mm long, branched, style branches $0.2 \mathrm{~mm}$ long, linear with pollen sweeping hairs, which cover the style below the point of bifurcation for the same length as that of the branches. Anthers minutely caudate, linear with ovate apical appendages. Ovary up to $2 \mathrm{~mm}$ long. Cypselae 3.0-3.5 mm long, glabrous, 3 -ribbed, narrowly obovate and the surface is rugose and papillate. Flowering time: October-May. Figure 1G, 2F $\& 9$.
Distribution and habitat: Garuleum pinnatifidum is recorded throughout the Great Karoo, from GraaffReinet to Cradock and into the Free State as far north as Bloemfontein, Thaba Nchu and Rouxville (Figure 10), 765-1 $705 \mathrm{~m}$. The species grows on mountain and hill slopes, along the road, in loamy and sandy soils in grassland and False Karoo.

Diagnosis: distinguished from other species by having 1-pinnate leaves and firm involucral bracts; covered in glandular-scabrid hairs.

\section{Additional specimens}

FREE STATE.-2826 (Brandfort); Bloemfontein, Glen Agriculture College, (-CD), 22 Mar. 1951, Mostert 9 (PRE); Bloemfontein, Glen Agriculture College, (-CD), 18 Mar. 1985, Zietsman \& Zietsman 329 (PRE). 2827 (Senekal): Winburg, Willem Pretorius Game Reserve, (-AC), 10 Apr. 1962, Leistner 2998 (PRE); Willem Pretorius Game Reserve, (-AC), 20 Jan. 1972, Muller 835 (PRE); Doornkop, (-DD), 2 Dec. 1931, Goossens 730 (PRE). 2925 (Jagersfontein): Edenburg, Bethanië, (-DB), 1 Feb. 1996, Peyper 2013 (PRE). 2926 Wintervalley, $\mathrm{N}$ of Bloemfontein underneath trees below $\mathrm{S}$ slope of koppie, (AA), 26 Mar. 1968, Muller 204 (PRE); Thaba Nchu, Adelaide, (-BB), 4 Dec. 1963, Roberts 2911 (PRE); Thaba Nchu, Dakpoort Flats, (BD), 4 Dec. 1963, Roberts 2923 (PRE); Dewetsdorp, (-DA), 15 Apr. 1950, Steyn 926 (NBG). 2927 (Maseru): Wepener, (-CA), 29 Jan. 1945, Acocks 11169 (PRE). 3026 (Aliwal North): Gryskop, 24 km N of Rouxville on slope of hill, (-BB), 8 Feb. 1986, Welman 719 (PRE).

EASTERN CAPE.-3124 (Hanover): Middelburg, Carlton hills, (-BD), 27 Mar. 1947, Acocks 13541 (PRE); Richmond, Rhenosterfontein, S of Richmond, (-CA), 27 Apr. 1950, Acocks 15835 (PRE); Richmond, Roelofsfontein, (-DA), 25 Nov. 1972, Hanekom 1954 (PRE); Graaff-Reinet, Blue Gum House Farm, in front of house, (-DD), 14 Oct. 1983, Retief \& Reid 533 (PRE). 3223 (Rietbron): Willowmore, Van Rooyenskraal Farm, along tributary of Hopsrivier, (DD), 11 Oct. 1983, Retief \& Reid 441 (PRE). 3224 (Graaff-Reinet): Moordenaarsrivier; Houd Constant Pass S of farm to river, (-AA), 7 Nov. 1974, Oliver 5268 (PRE); Graaff-Reinet, Wimbledon, (-BC), 8 May 1954, Henrici 4991 (PRE); Graaff-Reinet, 9 miles [14.4 km] N of Graaff-Reinet, (-BC), 10 Feb. 1955, Adamson D.211 (PRE). 3225 (Somerset East): Cradock, Mountain Zebra National Park, (-AB), 26 Mar. 1952, Brynard 13 (PRE); Cradock, Mountain Zebra National Park, near dam at house, (-AB), 4 May 1963, Liebenberg 7239 (PRE); Cradock; Mountain Zebra National Park, (-AB), 21 Apr. 1969, Müller 628 (PRE); Cradock, Mountain Zebra National Park, (-AB), 25 Jan. 1966, Liebenberg 7635 (PRE); Cradock, Mountain Zebra National Park, (-AD), 30 Oct. 1985, Zietsman \& Zietsman 1286 (PRE); Mountain Zebra National Park, (-AD), 12 Dec. 2005, Bester 6309 (PRE); Uniondale, 7 miles [11.2 km] from Uniondale along road from Uniondale to Willowmore, (-CB), 23 June 1961, Van Breda 1190 (PRE). 3324 (Steytlerville): Steytlerville, (-AD), 9 Nov. 1950, Theron 908 (PRE).

8. Garuleum schinzii O.Hoffm. in Bulletin de L'Herbier Boisseir 1: 74 (1893); Merxm. 139: 71 (1967); Merxm.: 34 (1954). Type: Namibia, Tiras, 21 Apr. 1875, Schinz 698 (Z-digital image!, holo.).

Viscid, aromatic, much branched subshrub from a woody stem, $0.2-1.0 \mathrm{~m}$ high. Stem $3-5 \mathrm{~mm}$ thick, glandular-hispid, ribbed. Leaves alternate, sessile, globose glands, lower leaves irregularly bipinnatipartite or almost tripinnatipartite with short linear segments, upper ones reduced, simply pinnatifid. Capitula radiate, pedunculate. Peduncles up to $90 \mathrm{~mm}$ long, mostly solitary, ribbed, shortly hirsute, bracteate, some hairs with glandular tips. Involucre hemispherical, up to $15 \mathrm{~mm}$ diameter when pressed. Involucral bracts in 2-series, imbricate, finely pubescent, narrowly lanceolate, acuminate; outer ones 4.5-5.0 × $1.0 \mathrm{~mm}$; inner ones $6.0-7.0 \times$ $1.1 \mathrm{~mm}$ with coloured apex. Ray florets female, fertile, blue; corolla limb up to $15.0 \times 1.5 \mathrm{~mm}$, narrowly lin- 


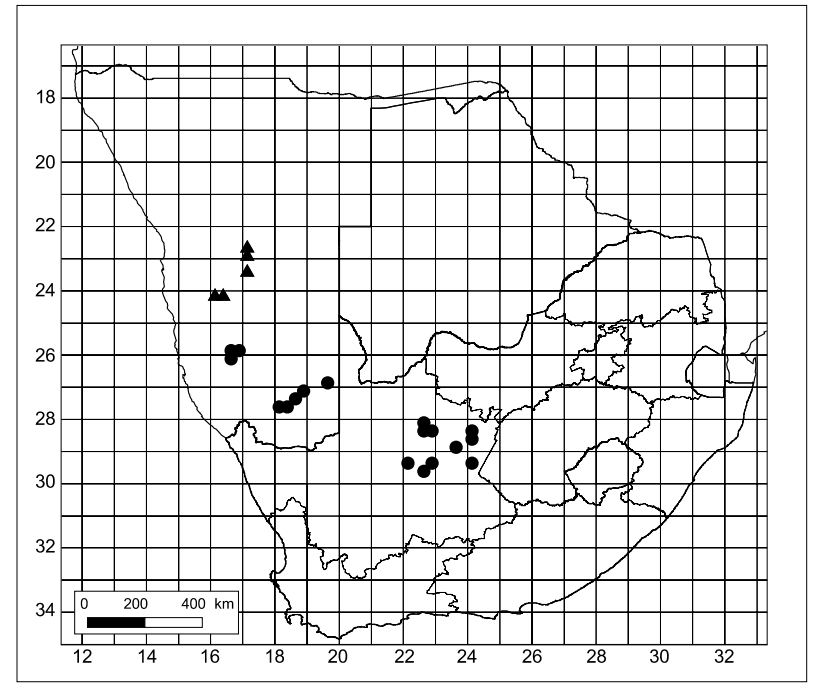

FIGURE 11.-Distribution of Garuleum schinzii subsp. schinzii G schinzii subsp. crinitum $\boldsymbol{\Delta}$.

ear; corolla tube up to $4 \mathrm{~mm}$ long, glandular, cylindric. Style 4.5-5.0 mm long, branched, linear, style branches $2.2 \mathrm{~mm}$ long. Ovary up to $2.2 \mathrm{~mm}$ long, glabrous, obovate in outline. Disc florets functionally male, yellow, 5-lobed; lobes ovate, $0.2 \mathrm{~mm}$ long; corolla limb 4.0-4.2 $\mathrm{mm}$ long; corolla tube $2.5-3.0 \mathrm{~mm}$ long, glandular. Style $3.8-4.0 \mathrm{~mm}$ long, bifid bearing sweeping hairs all way to below division but lacking papillae, linear. Anthers minutely caudate, linear with ovate apical appendages. Ovary up to $2.0 \mathrm{~mm}$ long. Cypselae $4.0 \mathrm{~mm}$ long, glabrous, slightly curved, three-angled, obpyramidial, strongly rugose. Flowering time: throughout the year.

Diagnosis: distinguished from other Garuleum species by its bipinnate leaves and loose involucral bracts covered with glandular-pilose hairs.

Merxmüller (1967) separated schinzii in into two subspecies. In Garuleum schinzii subsp. schinzii, the ray florets are blue, this species prefers limestone, shale and calcareous soils. It occurs from Bethanien District, Aus down to Klein Karas (Namibia) and from Langeberg Range to Barkly West as far south as Belmont (Northern Cape Province). In Garuleum schinzii subsp. crinitum, the ray florets are white; this species prefers dolomite soils and it occurs from Windhoek and Rehobot as far south as Bullesport Mountains (Namibia).

Key to subspecies:

1a. Ray florets blue; peduncles up to $90 \mathrm{~mm}$ long ... . . . . . . . $\ldots \ldots \ldots \ldots \ldots \ldots \ldots \ldots \ldots$ 8a subsp. schinzii

1b. Ray florets white; peduncles $40-60 \mathrm{~mm}$ long . . . . . . . . . 8b. subsp. crinitum

\section{8a. subsp. schinzii}

Lower leaves irregularly bipinnatipartite or almost tripinnatipartite with short linear segments, upper leaves reduced, simply pinnatifid. Peduncles up to $90 \mathrm{~mm}$ long. Ray florets blue. Cypselae $4.0 \mathrm{~mm}$ long, glabrous, slightly curved, three-angled, obpyramidial, strongly rugose. Flowering time: throughout the year (Figure $1 \mathrm{H}$ \& $2 \mathrm{G})$.
Distribution and habitat: found in Namibia (Bethanien District, Aus down to Klein Karas) and Northern Cape Province, from Langeberg Range to Barkly West as far south as Belmont, (Figure 11), 1 069-1 $145 \mathrm{~m}$, occurring on hill slopes, along roads, in valleys, on limestone, shale, calcareous sands and dry riverbeds.

\section{Additional specimens}

NAMIBIA.-2217 (-CC), Windhoek, hills between Windhoek \& Rehoboth, 14 Mar. 1988, Goldblatt \& Manning 8797. 2516 (Helmeringhausen): Kunjas, W of Helmeringhausen, (-DC), 9 May 1976, Oliver, Muller \& Steenkamp 6478 (PRE); Maltahohe, dry riverbed near road to Maltahohe, (-DD), 16 Apr. 1949, Kinges 2103 (PRE); Bethanien, Goais, (-DD), 19 May 1965, Giess 8816 (PRE). 2616 (Aus): Frisgewaagd, (-BA), 3 Apr. 1968, Giess 10274; Keetmanshoop, Aroab 3 miles [4.8 km] W of Aroab, (-DC), 2 May 1955, De Winter 3368 (PRE). 2718 (Grüna): Great Karasberg, Genadendal, S end of the Great Karasberg slopes in main kloof, (-BC), 5 May 1976, Oliver \& Steenkamp 6306 (PRE); Great Namaqualand, Klein Karas, (-CA), 8 Apr. 1931, Ortendahl 34 (PRE); Klein Karas, (-CA), 2 Aug. 1923, Dinter 4810 (PRE).

NORTHERN CAPE.-2822 (Glen Lyon): about $24.8 \mathrm{~km}$ west of Olifantshoek on Pearson's Hunt road in a poort in Langeberge, (-BA), 10 Aug. 2000, Smook 10965 (PRE); Olifantshoek, $24.8 \mathrm{~km} \mathrm{NW}$ of town on road to Pearson's Hunt, (-BA), 10 Aug. 2000, Meyer 2887 (PRE); Langeberg Range, Dunmurray; W slopes of Langeberg Range, (-BC), 22 Mar. 1920, Pole Evans 87 (PRE); Hay, Floradale, foot of hills, (-BD), Apr. 1940, Esterhuysen 2325 (PRE); Postmasburg, Klipbank, (-BD), 17 Jan. 1958, Repton 4777 (PRE). 2823 (Griekwastad): Hay, Swartkop, Black Jasper Hills, (-CD), 31 July 1936, Acocks 544 (PRE); Herbert, Campbell, 8.5 miles [13.6 km] NE of Campbell, (DC), 27 Sept. 1957, Leistner 914 (PRE). 2824 (Kimberley): Barkly West, Kransfontein, (-AC), Aug. 1936, Paton MCG.M.3737 (PRE); Herbert, Schmidtsdrift, 9 miles NW of Schmidtsdrift slopes, (-CA), 25 Aug. 1961, Leistner \& Joynt 693 (PRE); Caerwinning, (-DA), 7 Oct. 1937, Ferrar 31884 (NH). 2922 (Prieska): Marydale, 6.5 miles [10.4 km] S of Marydale, (-AC), 10 May 1946, Story 1224 (PRE); Niekerkshoop, (-BD), Vermeulen TRV 23453 (PRE); 15 miles NW of Prieska, (-DA), 13 May 1961, Schlieben 8793 (PRE); $60 \mathrm{~km}$ from Marydale on Prieska road, (-DA), 8 June 1977, Smook \& Harding 719 (PRE); Prieska valley and lower hills, (-DA), 18 Feb. 1920, Bryant J40 (PRE). 2924 (Hopetown): Kimberley, Belmont, Fort Richmond, (AC), Sept. 1950, Waylands PRE 44121 (PRE).

8b. subsp. crinitum (Dinter) Merxm. in Mitteilungen der Botanischen Staatssammlung München 2: 34. (1954); Merxm. 139: 71 (1967). G. crinitum Dinter in Feddes Repertorium 30: 184 (1932); Merxm. 139: 71 (1967). Type: Namibia, (Hereroland), Auas Mountain, Dinter 4654 (B, lecto., designated by Merxmüller: 34 (1954); PRE!, isolecto).

G. bipinnatum auct. Dinter: 308 (1921), non (Thunb.) Less. (1832).

Leaves pinnatifid, 8-12 × 3-4 cm long. Peduncles 40-60 mm long. Ray florets white. Cypselae $3.5 \mathrm{~mm}$ long, glabrous, obpyramidial, bluntly triangular and the surface is glandular and rugose. Flowering time: February-May. Figure 1I, $2 \mathrm{H}$.

Distribution and habitat: Garuleum schinzii subsp. crinitum is endemic to Namibia, from Windhoek and Rehobot as far south as Bullesport Mountains (Figure 11), preferring mountain slopes, dolomite soils.

\section{Additional specimens}

NAMIBIA. - 2217 (Windhoek): Avis Dam near Windhoek, (-CA), 21 Feb. 1959, Seydel 1715 (PRE). 2317 (Rehoboth): Bergland, Farm 264, (-AC), 19 Dec. 1957, Merxmüller 826 (PRE). 2416 (Maltahohe): Naukluft plateau, W of Kapokvlakte, track to Beacon 1949, (-AA), 23 Mar. 1995, Burke 9564 (PRE); Naukluft, (-AB), 16 May 1978, Muller 
\& Tilson 860 (PRE); Rehoboth, Buellsport Mtn, (-AB), 26 Mar. 1948, Strey 2305 (PRE).

\section{ACKNOWLEDGEMENTS}

My colleagues from the South African National Biodiversity Institute, namely P. Herman for guidance and discussions, Hester Steyn for producing the distribution maps, and Gillian Condy for kindly preparing the line drawing. Dr Leistner for the translation of Latin text. Referees for their valuable comments. Curators and staff of NH, GRA and NBG herbaria, for making material available on loan. The author would also like to express gratitude to the curator and staff of Melbourne herbarium and Trinity College Dublin for sending digital image of type material.

\section{REFERENCES}

AITON, W. 1789. Hortus Kewensis. Vol. III. Diadelphia-Cryptogamia. George Nicol, London.

BREMER, K. 1994. Asteraceae: cladistics and classification. Timber Press, Portland, Oregon.

CANDOLlE, A.P. DE. 1836. Compositae. Prodromus 5. Treuttel \& Würtz, Paris.

CANDOLlE, A.P. DE. 1838. Compositae. Prodromus 6. Treuttel \& Würtz, Paris

CASSINI, A.H.G. DE. 1819. Description des nouveaux genres Garuleum et Phaganalon; par M. Henri Cassini. Bulletin de la Société Philomatique de Paris November: 172.

CASSINI, A.H.G. DE. 1819. Dictionnaire des sciences naturelles 18: 163. Ed. F.Cuvier. edn 2. Le Normant, Paris.

CLAASSEN, C. 1970. Asteraceae. Garuleum album. Flowering plants of Africa. Vol. 40: t. 1593.

DINTER, K. 1921. Index, der aus Deutsch-Südwestafrika bis zum Jahre 1917 bekannt gewordenen Pflanzenarten. IX. Feddes Repertorium 17: 308

DINTER, K. 1932. Diagnosen neuer Südwestafrikanischer Pflanzen. Feddes Repertorium 30: 184

GOLDBLATT, P. \& MANNING, J. 2000. Cape Plants. A conspectus of the Cape flora of South Africa. Strelitzia 9. National Botanical Institute of South Africa, Cape Town.

HARVEY, W.H. 1865. Compositae. Flora capensis 3: 44-530.

HERMAN, P.P.J., RETIEF, E., KOEKEMOER, M. \& WELMAN, W.G. 2000. Asteraceae. In O.A. Leistner, Seed plants of southern Africa: families and genera. Strelitzia 10: 101-170. National Botanical Institute, Pretoria.

HERMAN, P.P.J., WELMAN, W.G., RETIEF, E., KOEKEMOER, M. \& NETNOU, N. 2003. Asteraceae. In G. Germishuizen \& N.L. Meyer, Plants of southern Africa: an annotated checklist. Strelitzia 14: 217. National Botanical Institute, Pretoria.

HILLIARD, O.M. 1977. Compositae in Natal. University of Natal Press, Pietermaritzburg, South Africa.

HOFFMANN, O. 1893. Compositae. Garuleum schinzii. In H. Schinz, Bulletin de L'Herbier Boissier 1: 74.
HOLMGREN, P.K., HOLMGREN, N.H. \& BARNETT, L.C. 1990 Index herbariorum, part 1: the herbaria of the World. New York Botanical Garden, New York.

JACKSON, W.P.U. 1990. Origins and meanings of names of South African plant genera. Pteridophytes, gymnosperms and monocotyledonous angiosperms. University of Cape Town, South Africa.

JACQUIN, N.J.B. 1786. Osteospermum caeruleum. Collectanea ad Botanicum, Chemiam, Historiam Naturalem. Vol. 1. pg. 78, 79. Vindobonae.

JUEL, H.O. 1918. Plantae thunbergianae. Uppsala.

LESSING, C.F. 1832. Asteraceae. Garuleum bipinnatum Less. Synopsis generum compositarum. Duncker \& Humblot, Berlin. pp. 194

L'HERITIER DE BRUTELLE, C. 1785. Stirpes novae aut minus cognitae. pp. 11 tab 6.

LINNAEUS, C. VON, f. 1782. Asteraceae. Osteospermum calendulaceum L.f. Supplementum Plantarum: 386.

MACOWAN, P. 1889. Compositae, Tribe Calendulaceae. Osteospermum tanacetifolium. Hooker's Icones Plantarum 19, Plate 1839.

MERMÜLLER, H. 1954. Compositen-Studien 4: Die Compositen-Gattungen Südwestafrikas. Mitteilungen der Botanischen Staatssammlung München 2: 34.

MERXMÜLLER, H. 1967. Asteraceae. Prodromus einer Flora von Südwestafrica 139: 71, 72 .

MOORE, S. LE M. 1878. Alabastra diversa. Journal of Botany 16: 133.

NORDENSTAM, B. 1994. Tribe Calenduleae. In K. Bremer, Asteraceae, cladistics and classification: 365-376. Timber Press, Oregon.

NORDENSTAM, B. 2007. XIII. Tribe Calenduleae Cass. (1819). In K. Kubitzki. The families and genera of vascular plants. VIII. Flowering Plants-Eudicots, Asterales (eds J.W. Kadereit \& C. Jeffrey): 241-245. Springer, Berlin.

NORLINDH, T. 1943. Studies in the Calenduleae. I. Monograph of the genera Dimorphotheca, Castalis, Osteospermum, Gibbaria and Chrysanthemoides. Gleerup, Lund.

NORLINDH, T. 1977. Garuleum subgenera Rutidocarpaea, a monotypic subgenus showing achene dimorphism. Botaniska Notiser 130: 377-380.

PFEIFFER, L.K.G. 1874. Nomenclator Botanicus. Vol. 1: 1411-1412. Kassel, Fischer.

RAIMONDO, D., VON STADEN, L., FODEN, W., VICTOR, J.E., HELME, N.A. TURNER, R.C., KUMUNDI, D.A. \& MANYAMA, P.A. 2009. Red List of South African plants. Strelitzia 25. South African National Biodiversity Institute, Pretoria.

SCHINZ, H. 1895. Compositae: Garuleum woodii. Bulletin de L'Herbier Boissier 3: 440.

STAFLEU, F.A. \& COWAN, R.S. 1981. Taxonomic literature. A selective guide to botanical publications and collections with dates, commentaries and types. Vol. 3.

SWELANKOMO, N. 2010. Garuleum bipinnatum (Thunb.) Less. http://www.plantzafrica.com/plantefg/garulbip.htm.

THUNBERG, C.P. 1800. Prodromus plantarum capensium 2. Uppsala. pp. 167.

THUNBERG, C.P. 1825. Flora capensis. Ed. Schultes. Stuttgart. pp. 717.

VAN BREDA, P.A.B. \& BARNARD, S.A. 1987. Veld plants. A.9 Gifhoutjie. Farming in South Africa, Pamphlet: Winter rainfall region. Department of Agriculture and Water Supply, Pretoria.

WATT, J.M. \& BREYER-BRANDWIJK, M.G. 1962. The medicinal and poisonous plants of southern and eastern Africa. Livingstone, Edinburgh. 